\title{
International Journal of

\section{R\&D and human capital policies as determinant factors for a company's performance and profitability}

Elena Valentina Țilică*1

*Department of Finance, Bucharest University of Economic Studies, Romania

\begin{tabular}{ll}
\hline ARTICLE INFO & A \\
\hline Article History & P \\
& Received 25 September 2020 \\
Accepted 8 March 2021 & t \\
\hline JEL Classifications & T \\
G30 & Th
\end{tabular}
ABSTRACT Purpose:

This paper investigates the impact of $\mathrm{R} \& \mathrm{D}$ expenses and human capital related indicators on the performance and profitability of companies from the European pharmaceutical sector.

Design/methodology/approach:

The database includes 26 listed companies from different European countries in the period 2011-2017. The study consists in a panel data analysis, using either fixed or random effects based on the results of the Hausman test.

Findings:

The results show that $\mathrm{R} \& \mathrm{D}$ expenses and CEO-chairman duality have a positive impact both on a company's performance and profitability and their effects can be seen starting with the year they were employed. However, a CEO change has a more pronounced impact on performance indicators which is observed starting with the year following the one it was performed. Furthermore, while pension related expenses prove to have no effect on either profitability rates or performance margins, an increase of employee productivity shows a positive impact only on the company's performance.

Research limitations/implications:

These results show that all parties interested in the development of a company and the increase of its profitability will have a tough mission when trying to find the correct policies to implement, as some that improve a firm's performance might not influence its profitability. Nonetheless, R\&D related expenses could provide a solid policy for the European pharmaceutical sector as they appear to have a positive impact on both profitability and performance. However, the relative low number of companies included in the database limits the degree of generalization of the obtained results, especially considering a global perspective. Furthermore, the short analysis period could generate biased results when considering the impact of the human capital indicators on a company's results as their impact could be seen in a more prolonged time. In order to test the robustness of the findings, additional years should be included in the database, taking into consideration also non-stable periods.

Originality/value:

Keywords: profitability rates; company performance; human capital; R\&D expenses; CEO-

chairman duality
The paper includes a wide array of indicators (related to $\mathrm{R} \& \mathrm{D}$, corporate governance and human capital, alongside the typical financial indicators) to provide a comprehensive picture of the possible determinants of a company's profitability and performance.

\section{Introduction}

A company's performance is a well-studied theme in financial literature as maximizing a company's profit represented the main purpose of a good financial management process, given the shareholders interest for this indicator (Dragotă et al., 2012). In time, the view expanded to include the interest of all other stakeholders: employees, customers, 
suppliers, communities and governments. Because, oftentimes, these categories have different expectations, a company has difficulties pleasing all of them. Thus, the policies it implements have to be chosen carefully in order to balance all of the stakeholders' interests while also adapting to the changing demands of the economic environment.

When talking about a company's performance, financial literature has proposed several interpretations of this concept, based on the financial conditions present on the market and, also, the perspective of the different categories of investors. In the beginning, most studies defined a company's performance as its profitability, represented by its net return. However, in time, the economic environment became more complicated, and the simple fact of having a high net return became insufficient to insure the prosperous development of a company. Due to problems in, for example, cashing in their earnings from clients, the concept was updated by including, simultaneously, a high net return and a positive cash-flow.

Presumably, shareholders would be satisfied by having a high return, even though the level that is considered high enough for this indicator is somewhat subjective. However, creditors and employees are dependent on a firm's capacity to have earnings, in order to be able to pay the fees and salaries. For this reason, in financial literature, there are multiple indicators defined as related to a company's performance or profitability which take into account the different needs of the stakeholders. Moreover, in order to make these concepts less subjective (in regard to what level is considered to be good enough) and to increase their comparability, these indicators are presented as ratios.

The pivotal importance of this theme is also supported by the constant competition companies from the same sector face to attract continuous funding (either from shareholders or creditors), the best employees (in terms of both knowledge and efficiency) and a high number of customers by offering the best possible product on the market (either best quality, best price or a combination of the two). By reaching these goals, a management team would succeed in positioning the company in the forefront of the race for long-term development and profitability. The pharmaceutical sector is all the more influenced by the policies implemented to reach these goals, as their research and development (hereafter, R\&D) projects need substantial financing and should be implemented constantly in order to discover new drugs or improve the existing ones.

The current paper endeavours to provide useful insights regarding the impact of certain human capital-related policies (labour-related expenses, CEO-chairman duality, the CEO change) and R\&D investments on the improvement of a pharmaceutical company's performance and profitability. The results could be used by practitioners (the managerial staff) to choose the needed strategy, based on which policy is the most likely to yield the desired goal. Additionally, academics could find this paper a starting point to forecast the implications of the current healthcare crisis on the pharmaceutical sector and develop a plan for a sustainable development of the domain.

The remainder of the paper is structured as follows. Section 2 provides a brief description of the perspective given by financial literature on the three main concepts used in the analysis: firm performance and profitability, its financial determinants and the impact of human capital. Section 3 presents the database used in the analysis and the tested hypotheses, while the methodology is detailed in section 4. Section 5 depicts the results, split in three major directions: the determinants of a company's performance, the determinants of a company's profitability and the impact of human-capital related indicators' variation on performance and profitability. Section 6 provides the conclusions of the paper.

\section{Review of Literature}

\subsection{Firm performance and profitability}

There are various indicators used to study a firm's profitability, viewed in the narrow sense which can be linked, primarily to its net profit. The most commonly used in literature are: the return on assets (ROA), return on equity (ROE) or return on invested capital (ROIC). Return on equity specifically targets a shareholders' perspective by considering what they earn through the investment in this company. In a financially sound firm, this rate will be higher that ROA or ROIC because shareholders have the highest risk, so they should also register the highest return. Return on assets is the company's return obtained by using its assets. In some studies, like Deloof (2003), financial assets are removed from the value of total assets when determining ROA because these assets have little contribution to the net profit of a company, if it is not a financial institution. Return on invested capital shows the return obtained by both shareholders and creditors through their investment in the company. This rate is a weighted average between $\mathrm{ROE}$ and the average interest rate paid by the company to its creditors. Thus, modifying the capital structure of a company (percentage of equity and of debt) can be a method for the management to change this rate of return.

Hirshey and Wichern (1984) showed that both accounting-based and market-value indicators can be used to present a company's performance, both categories creating a consistent, but imperfect picture of the firm's situation. They suggest to use Return on Assets and Return on Equity as accounting measures of profitability. For the marketbased indicators, they consider the $\mathrm{Q}$ ratio, which is defined as the market-value of the firm divided by the replacement cost of the tangible assets.

In order to perform a broader analysis of a company's profitability, the following four indicators can be included, alongside the previously presented ones. They are connected to the firm's performance, by showing what percentage of its main income source (total sales) transforms into a profit for the company. Return on sale (ROS or net margin) 
shows the percentage of sales that becomes net profit for the company. The operating margin (OPS) takes into account only the results linked to the company's activity (revenues and costs of doing business), not being influenced by the financing method (without the influence of paid interests). The Gross Margin excludes the impact of the taxation process, by taking into account the whole gross profit of a company. The EBITDA margin considers only the impact of the basic firm's activity, excluding the amortization, financing and taxation processes. While ROS depicts the results obtained by shareholders, the other margins offer the possibility to compare the results of companies from different countries (where the taxation level might differ), different sectors or different time periods (when the amortization and financing structure might suffer variations).

Table 1 highlights some of the most common indicators used in financial literature following the accounting-based perspective, as this is the point of view that will be used later in this paper.

Table 1. Performance or profitability indicators

\begin{tabular}{|c|c|c|c|}
\hline Abrev. & Name & Formula & Found in studies: \\
\hline $\mathrm{ROE}$ & $\begin{array}{l}\text { Return on } \\
\text { equity }\end{array}$ & $\frac{\text { Net profit }}{\text { Owner's equity }}$ & $\begin{array}{l}\text { Dewenter and Malatesta(2001), Pantea et al. (2014), Ibhagui and } \\
\text { Olokoyo (2018), Padochi (2006), Duru et al. (2016), Wangari et.al } \\
\text { (2019), Killins (2020) }\end{array}$ \\
\hline $\mathrm{ROA}$ & $\begin{array}{l}\text { Return on } \\
\text { assets }\end{array}$ & $\frac{\text { Net profit }}{\text { Total assets }}$ & $\begin{array}{l}\text { Dewenter and Malatesta(2001), Joh(2003), Pantea et al. (2014), } \\
\text { Duru et al. (2016), Ibhagui and Olokoyo (2018), Rodrigues and } \\
\text { Rodrigues (2018), Pais and Gama (2015), Grau and Reig (2018), } \\
\text { Nanda and Panda(2018), Wangari et.al (2019), Hsu et al. (2019), } \\
\text { Killins (2020) }\end{array}$ \\
\hline ROIC & $\begin{array}{l}\text { Return on } \\
\text { invested } \\
\text { capital }\end{array}$ & $\frac{\text { Net profit }+ \text { Interest }}{\text { Invested capital }}$ & Rumpelt(1982) \\
\hline $\begin{array}{l}\text { ROS } \\
(\mathrm{NMG})\end{array}$ & $\begin{array}{l}\text { Return on } \\
\text { sales } \\
\text { (net margin) }\end{array}$ & $\frac{\text { Net profit }}{\text { Sales }}$ & $\begin{array}{l}\text { Dewenter and Malatesta (2001), Duru et al. (2016), Mun and } \\
\text { Jang(2018), Rodrigues and Rodrigues (2018), Nanda and Panda } \\
\text { (2018), Huang and Hou(2019) }\end{array}$ \\
\hline OPS & $\begin{array}{l}\text { Operating } \\
\text { margin }\end{array}$ & $\frac{\text { EBIT }}{\text { Sales }}$ & Rodrigues and Rodrigues (2018), Akintoye (2008) \\
\hline GRMG & $\begin{array}{l}\text { Gross } \\
\text { margin }\end{array}$ & $\frac{\text { Gross profit }}{\text { Sales }}$ & $\begin{array}{l}\text { Yu et al. (2017), Rodrigues and Rodrigues (2018), Murimi et al. } \\
(2019)\end{array}$ \\
\hline EBMG & $\begin{array}{l}\text { EBITDA } \\
\text { margin }\end{array}$ & $\frac{\text { EBITDA }}{\text { Sales }}$ & Rodrigues and Rodrigues (2018) \\
\hline
\end{tabular}

\subsection{Financial determinants of firms' profitability}

By considering either one or more of the indicators presented before, numerous papers have looked for possible determinants of firms' profitability as ways that could help managers insure higher profits without endangering the long-term perspectives. On one hand, different financial indicators have been studied, while, on the other hand, other factors were analyzed, like the impact of the human capital or corporate social responsibility policies. This section will focus on the first category, for which financial literature has offered numerous possibilities, linked to different aspects of a firm's activity. Table 2 presents a brief summary of the main financial indicators used for this type of analysis. Some of these indicators were included in the current paper based on the methodology presented in the next section.

Table 2. List of financial indicators studied as determinants of profitability and/or performance

\begin{tabular}{|l|l|l|l|}
\hline $\begin{array}{l}\text { Financial } \\
\text { indicator }\end{array}$ & Formula: & Found in studies: & $\begin{array}{l}\text { Found } \\
\text { impact: }\end{array}$ \\
\hline \begin{tabular}{l} 
Tangible or $\begin{array}{l}\text { intangible assets } \\
\text { (\% of total assets) }\end{array}$ \\
\hline Company size
\end{tabular} & Tang. or intang. assets & $\begin{array}{l}\text { Pantea et al. (2014), Grau and Reig (2018), Hsu et al. } \\
(2019)\end{array}$ & + \\
\hline Company size & $\log$ (Total revenue) & $\begin{array}{l}\text { Dewenter and Malatesta (2001), Deloof (2003), Pantea et } \\
\text { al. (2014), Ibhagui and Olokoyo (2018), Huang and } \\
\text { Hou(2019) }\end{array}$ & + \\
\hline
\end{tabular}




\begin{tabular}{|l|l|l|c|}
\hline $\begin{array}{l}\text { Liquidity } \\
\text { (current ratio) }\end{array}$ & \multicolumn{1}{c|}{$\begin{array}{c}\text { Current assets } \\
\text { Current liabilities }\end{array}$} & $\begin{array}{l}\text { Rodrigues and Rodrigues (2018), Grau and Reig (2018), } \\
\text { Nanda and Panda(2018) }\end{array}$ & + \\
\hline Liquidity & $\frac{\text { Cash \& short term inv. }}{\text { Assets }}$ & Killins (2020) & + \\
\hline Leverage & $\frac{\text { Long term debt }}{\text { Shareholder }{ }^{\text {s equity }}}$ & Deloof (2003), Nanda and Panda(2018) & - \\
\hline Debt & $\frac{\text { Long term or total debt }}{\text { Total assets }}$ & $\begin{array}{l}\text { Duru et al. (2016), Rodrigues and Rodrigues (2018), } \\
\text { Ibhagui and Olokoyo (2018), Hsu et al. (2019) }\end{array}$ & - \\
\hline $\begin{array}{l}\text { Accounts } \\
\text { receivables } \\
\text { (no.of days) }\end{array}$ & $\frac{\text { Acc. receiv. }}{\text { Total revenue }} \times 360$ & Deloof (2003), Pais and Gama (2015) & - \\
\hline $\begin{array}{l}\text { Accounts payable } \\
\text { (no.of days) }\end{array}$ & $\frac{\text { Acc. pay. }}{\text { Total revenue }} \times 360$ & Deloof (2003), Pais and Gama (2015) & - \\
\hline
\end{tabular}

These are just a few of the studies conducted on this subject which highlights the continued interest the financial literature has shown for it, throughout a long period of time. The used approach varied between these articles, based on the perspective the author had or the data they used (e.g. Dewenter and Malatesta, 2001 wanted to observe if there are any differences between the profitability of state-owned versus private companies from around the world, while Joh, 2003 was more interested in the impact of corporate governance on companies from Korea). However, their results lead to similar conclusions: the profitability of a company is obtained by compounding the effects of different aspects of a firm's activity, like its capacity to pay her current liabilities (liquidity), her long-term financing policy (leverage), her size, the management of her current activity (accounts payable, accounts receivable)

\subsection{Human capital as determinant of firms' profitability}

The concept of human capital has been a concern in economic literature for a long period of time, starting with the seminal works of Adam Smith (1776), Say (1971, first published in 1821) and List (1841). In time, human capital started to be taken into consideration as an important factor influencing the productivity of people (Schultz, 1961, Becker, 1962). More recently, it has been considered as a major factor in the enhancing of workers productivity and companies performance (Lucas, 1988). A more detailed presentation on the evolution of the human capital related economic literature is provided by Teixeira (2002).

Numerous definitions have been given which highlight the perspectives that are currently or were present at the time in literature. Becker at al. (2002) consider human capital as "the productive efforts of an organization's workforce". Chen et al (2004) postulate that "no value can be generated without human capital". Micah et al. (2012) include in human capital "the energies, skills, talents and knowledge of people" who are employed in the company. These are only a few of the given definitions which show that this concept includes many different aspects and can be evaluated from different perspectives. Some of the recent findings are presented next.

Veltri and Silvestri (2011) analyzed if information related to the intellectual capital is value relevant to the company's investors. Additionally, the authors evaluated the impact of the components of intellectual capital (human capital, organizational capital and relational capital) on the firm's value. Their results showed that shareholders take into account information related to intellectual capital in their firm evaluation process. Moreover, investors consider more value relevant the human capital component, compared to the other intellectual capital components.

Lafuente and Rabetino (2011) examine certain human capital indicators (employee education, previous work experience, employment motivations and the presence of family members in the firm) and their impact on company growth. The authors decided to use employment growth as a proxy for company growth, using two methods of computing it. Their results point to a positive relation between human capital indicators and employment growth. From a similar perspective, Avdullahi and Ademi (2020) analyze Small and Medium Enterprises' (SME) growth, through their sales increase. They show that an entrepreneur's education has no significant relation to the company's growth and, moreover, a female one could have a negative impact on the SME's growth. However, they prove that firm size (through employee number) and age show a positive impact on the company.

Onkelinx et al. (2016) observed companies' investment in employee human capital by determining the company's training cost per employee and developed a model that evaluates the effect of these investments on SME's productivity. They used as a productivity proxy the level of value added per worker. Additionally, the authors linked this productivity, to the company's degree of internationalization. Their results show that SME's with a strategy of rapid internationalization need employees with high levels of education and training which would increase their overall productivity. However, in companies with a gradual internationalization labour productivity is less critical. 
Detthamrong et. al (2017) analyzes the relation between corporate governance indicators and firm performance (seen as the return on equity). The human capital related indicators that are included in the study as independent variables are: board size, board independence, audit committee size, dummy for the female CEO situation and CEOchairman duality. Results show that board size and independence and the CEO being a woman have a positive lagged influence on firm profitability. However, audit committee size and CEO-chairman duality have a negative impact on profitability. However, Duru et al. (2016) found that board independence is linked to a positive impact of CEO duality on firm performance: a higher number of independent directors can transform the negative impact of CEO duality into a positive one. Other studies showed that the impact of the CEO duality on firms' profitability can be influenced by other external factors, like information costs. Hsu et al. (2019) showed that this factor enforces the negative impact of the CEO duality.

Fedyk and Hodson (2017) investigate the impact of human capital on financial performance. They viewed human capital through the employee turnover in a company and the skills of the workers. Their results suggest that a company's future return is negatively influenced by the employee turnover. Also, their findings indicate that a larger number of employees with sales-oriented skills lead to a better firm performance that a high number of employees with administrative skills.

Bendickson and Chandler (2019) study if human capital development programs can lead to positive outcomes in a firm's activity. Their results show that improvements in a company's operational performance can be obtained through these programs, which in turn lead to higher levels of revenues and sales.

The next section provides a detailed description of the database used in the analysis. Furthermore, it presents the hypotheses tested in the paper, based on the implications of other related studies.

\section{Database and tested hypotheses}

This paper studies the impact of both financial indicators and the human capital involvement on a company's profitability because both factors have been proven in literature to influence a firm's results. Additionally, financial indicators can be seen as control variables which help correctly identify the impact of the human capital-related ones.

The initial database consists in the 48 listed companies from the European pharmaceutical sector from the Thomson Reuters Europe Pharmaceuticals Index. Due to data unavailability of certain indicators' values or presumed database errors (negative total assets or debt values), some companies were removed from the database. Additionally, other companies were excluded from the database because they showed no variability in the indicators related to the management team (CEO duality or changing of the CEO). However, the remaining 26 companies included in the final database cover more than $79 \%$ of the European pharmaceutical listed companies (in terms of market capitalization, as shown in Appendix 1, Table A1). They are relatively large, ranging from a minimum of 300 to 124,000 employees and an average revenue (between 2011-2017) between 60 million euro to over 43,000 million euro. They are from different countries and branches of the sector thus providing a comprehensive overview of the European pharmaceutical environment.

The analyzed period is between 2011 and 2017, with the exception of ConvaTec Group which provided information only beginning 2013. The information was mainly provided by the Thomson Reuters Eikon database. Additional information regarding the changing of the chief executive officer (hereafter CEO) and the duality of the CEO and Chairman of Board of Directors (hereafter Chairman) was collected by hand from the internet sites of the companies.

Table 3 provides information about initial list of variables considered to be included in the analysis, which can be either dependent or independent variables. The dependent variables will be used consecutively as proxies for a company's profitability (ROE and ROIC) or a company's performance: the gross margin (hereafter GRMG), EBITDA margin (EBMG) and net margin (NMG). These indicators are calculated as previously presented in Table 1. The control variables are represented by highly known financial indicators. The current ratio is used as a liquidity proxy, for evaluating the short-term activity of the company. As a leverage proxy, either one of the three indicators was used: the assets to equity ratio (As_Eq), debt to equity ratio (D_eq) or the long-term debt as percentage of total capital (LTD_Cap). These present different perspectives of a company's financing policy.

Table 3. List of indicators included in the analysis

\begin{tabular}{|c|c|c|c|}
\hline Indicators & Abbreviation & Used as: & Variable type \\
\hline Gross Margin & GRMG & \multirow{3}{*}{ Performance proxy } & \multirow{5}{*}{ Dependent variable } \\
\hline EBITDA Margin & EBMG & & \\
\hline Net Margin & NMG & & \\
\hline Return on equity & ROE & \multirow{2}{*}{ Profitability proxy } & \\
\hline Return on invested capital & ROIC & & \\
\hline Current Ratio & Crat & Liquidity proxy & \multirow{3}{*}{$\begin{array}{l}\text { Independent } \\
\text { variable }\end{array}$} \\
\hline Assets/Equity & As_eq & \multirow{2}{*}{ Leverage proxy } & \\
\hline Debt/Equity & D_eq & & \\
\hline
\end{tabular}




\begin{tabular}{|c|c|c|}
\hline \% LT Debt to Total Capital & LTD_Cap & \\
\hline Revenue per employee & Rev_em & Human capital productivity \\
\hline Pension expenditure/Revenue & Pens_rev & \multirow{3}{*}{ Human capital expenditure } \\
\hline Administrative expenditure/Revenue & Adm_rev & \\
\hline Supplemental labour expenditure/Revenue & Supl_rev & \\
\hline $\begin{array}{l}\text { Research and development expenditure/ } \\
\text { Revenue }\end{array}$ & Rd_rev & Human capital innovation \\
\hline Changing of CEO, dummy variable & CEO_ch & \multirow{2}{*}{$\begin{array}{c}\text { Human capital in } \\
\text { management }\end{array}$} \\
\hline Duality CEO - Chairman, dummy variable & Dual & \\
\hline
\end{tabular}

When assessing the human capital, four perspectives were taken into consideration, as shown in Table 3, starting with evaluating the productivity of the human capital employed in the company. It is determined as the average annual revenue obtained for each employee. Yu et al. (2017) show that the growth in employee productivity "accounts for a substantial portion" of the firm's growth rate, seen as an increase of sales. As firm performance should be highly connected to its sales, the first tested hypothesis is: an increase of employee productivity will lead to a higher firm's performance and profitability.

Secondly, I considered the labour related expenses of the company. This category consists of the pension expenditures (aggregating the mandatory and voluntary ones), the administrative expenditure (which include mainly the ordinary expenses with employees, but also advertising services), the labour related supplemental expenditures (that include the occasional expenses a company has related to internal and/or external training courses or other labour related enhancing activities). These categories can be seen as expenses the company is obligated to make in order to continue its normal activity. In this case, the presumed impact of the labour related expenses on firms' profitability is negative, as observed by Mun and Jang (2018) or Killins (2020). The latter also found that the relation between some determinants and firm profitability can be time-varying. That suggests that, in certain situations, these expenses could be used by the company as a signal in the relation with their employees. For example, an increase of pension expenditures could show people that their employer is interested in their future, thus increasing their loyalty. Similarly, higher administrative (wage-related) expenses could increase employee motivation and loyalty, especially in a sector with a high demand of new personnel (like the pharmaceutical one) or in a period defined by job insecurity. Higher supplemental expenditures, generated by additional training courses, could lead to a more qualified, better functioning team of employees, as concluded by Bendickson and Chandler (2019). Thus, the second tested hypothesis is: higher labour related expenses will lead to a higher firm's performance and profitability, for the analysed period.

Additionally, I included the R\&D expenses. These can be seen as a control variable, as the pharmaceutical sector is one that relies primarily on constant innovation, due to the specifics of the domain. However, these expenses can also represent an investment the company makes in the development of new or improved products which, if successful, should lead to higher sales. Thus, the third tested hypothesis is: higher R\&D related expenses will lead to a higher firm's performance or profitability. This is in line with the conclusions of Huang and Hou(2019) who found a direct causality from "a firm's innovative activities to firm profitability".

The fourth perspective considers the human capital activity at the management level, by observing the moment when changes were made at the executive level (the change of the CEO) or if there is a duality between CEO and Chairman of the Board (the two management positions are not held by two different people). Literature suggests that CEO changes initially reduce a firm's profitability, but, in time, the company changes significantly (Beatty and Zajac, 1987). The views regarding the impact of the CEO-chairman duality on firm performance and profitability are split. Initially, a negative impact or the absence of one was reported (Cochran et al., 1985), but in more recent years, studies showed a positive relation between them (Boyd, 1995, Erhardt et. al, 2003). However, Duru et al. (2016) showed that the CEO duality-firm performance connection is more complicated. While CEO duality has a significant negative impact on performance, it can be "positively moderated by board independence". A similar conclusion is obtained by Hsu et al. (2019) which show that the negative impact of CEO duality is present when information costs are high. The present database consists in listed pharmaceutical firms, which are presumed to have a large percentage of independent directors and a high level of transparency. For this reason, the fourth tested hypothesis is: the CEO changing and the duality of CEO-chairman have a positive impact on the firm's performance and profitability.

The next section presents the general approach of the paper. It starts with the description of the methodology employed to choose which independent variables are included simultaneously in the model, based on their correlation. It continues by presenting the general form of the model used to determine their impact on a company's performance and profitability. Because the impact of the variables could appear both simultaneous (in the same year the variables are recorded) or with a time differential (the effects appear in the following year), both models are tested.

\section{Methodology}

To test the previously presented hypotheses, the panel data analysis is employed.. The descriptive statistics of the dependent variables are provided below, in Table 4. All these variables are determined as percentages which explains the relative low values. The maximum values above 1 (above 100\%) represent abnormal values registered by these 
indicators in some special circumstances. However, they are not frequent in the sample, which can be seen in the mean and median values, however they increase the standard deviation of the indicators.

Table 4. Descriptive statistics for the dependent variables

Source: Own calculations

\begin{tabular}{|l|c|c|c|c|c|}
\hline Variable & EBMG & GRMG & NMG & ROE & ROIC \\
\hline Mean & 0.28 & 0.66 & 0.16 & 0.31 & 0.20 \\
\hline Median & 0.28 & 0.69 & 0.13 & 0.14 & 0.09 \\
\hline Maximum & 0.72 & 0.94 & 4.10 & 12.38 & 7.19 \\
\hline Minimum & -0.09 & 0.16 & -0.48 & -0.51 & -0.36 \\
\hline Std. Dev. & 0.11 & 0.14 & 0.34 & 1.05 & 0.63 \\
\hline
\end{tabular}

The fact that the dependent variables are determined as percentages creates the need for the independent variables to be calculated in a similar manner as to not obtain results which are biased by the size effect. In the case of the indicators used as proxy for liquidity and leverage, this is not a problem because they are typically calculated as percentages. However, the company's expenditure related to its human capital (pension, administrative and supplemental labour expenditure) is typically determined in million euros. To make them comparable, these indicators were reported as percentage in total revenue. The indicators CEO_Ch and Dual are two dummy variables: CEO_Ch takes the value 1 in the years when the CEO of the company was changed and O otherwise and Dual takes the value $O$ in the years when the same person was the CEO and the Chairman of the company and 1 otherwise. All these indicators are used to test the second, third and fourth of the previously stated hypotheses.

Their descriptive statistics are presented in Table 5. For the liquidity and leverage proxies, they show that, while extremely large maximum levels can be seen (with the exception of Ltd_Cap), no negative values have been recorded. Additionally, the large values are infrequent, thus leading to reduced mean and median indicators. By looking at the CEO_Ch and Dual statistics, it can be observed that changes in management were not very frequent in the database (low values of mean and median), while a division of the CEO-Chairman positions between two people was a much more normal situation (high values of mean and median). Studying the human-capital related expenses' statistics shows that the one concerning the pension funds is extremely low compared to the other two. Furthermore, the administrative ones are higher and more stable across the database compared to the supplemental expenses which can be easily explained as the pharmaceutical sector is highly regulated one. An interesting observation is that the R\&D expenses appear to be lower than the supplemental ones, suggesting that the companies from the database are more inclined to invest in their employees' continued learning process than in the development of new products.

Table 5. Descriptive statistics for the initial independent variables

\begin{tabular}{|l|c|c|c|c|c|}
\hline Variable & Crat & As_Eq & D_Eq & Ltd_Cap & CEO_Ch \\
\hline Mean & 2.16 & 2.97 & 1.04 & 0.25 & 0.11 \\
\hline Median & 1.73 & 1.81 & 0.27 & 0.18 & 0.00 \\
\hline Maximum & 19.42 & 94.06 & 79.57 & 2.76 & 1.00 \\
\hline Minimum & 0.51 & 1.06 & 0.00 & 0.00 & 0.00 \\
\hline Std. Dev. & 1.85 & 8.07 & 6.18 & 0.34 & 0.31 \\
\hline Variable & Dual & Adm_Rev & Pens_Rev & Rd_Rev & Supl_Rev \\
\hline Mean & 0.61 & 0.31 & 0.01 & 0.11 & 0.16 \\
\hline Median & 1.00 & 0.31 & 0.01 & 0.12 & 0.22 \\
\hline Maximum & 1.00 & 0.69 & 0.03 & 0.38 & 0.54 \\
\hline Minimum & 0.00 & 0.02 & 0.00 & 0.00 & 0.00 \\
\hline Std. Dev. & 0.49 & 0.09 & 0.01 & 0.08 & 0.14 \\
\hline
\end{tabular}

Source: Own calculations

The revenue per employee is initially determined in euro. In order to make it comparable to the other indicators in the database, its annual percentage variation was determined. This is used to test the first stated hypothesis and lead to a second type of analysis: observing the impact that variations of the initial human capital related variables have on the performance and profitability of a company. Their descriptive statistics are presented in Table 6 . They show that the pension related expenses were relatively constant in the analyzed period, varying to only a degree of around $\pm 2 \%$. The administrative and supplemental expenses were significantly more volatile and registered considerable larger increases (maximum of $45 \%$ to $50 \%$ ) than decreases (minimum of $-14 \%$ to $-26 \%$ ). R\&D expenses appear to vary significantly less in the analyzed period and its increases seem lower than its decreases. The employee number seems 
to be the most volatile indicator. However, its variation is larger than $\pm 50 \%$ in only 5 cases ( 3 above $50 \%, 2$ below $50 \%)$. A similar situation is seen for employee productivity, the second most volatile indicator, where it's maximum variation is above $\pm 60 \%$.

Table 6. Descriptive statistics for the second analysis

\begin{tabular}{|l|c|c|c|c|c|c|}
\hline Variable & M_ADM & M_PENS & M_SUPL & M_REVEM & M_EMPL & M_RD \\
\hline Mean & $0.7 \%$ & $0.0 \%$ & $3.0 \%$ & $3.3 \%$ & $5.7 \%$ & $-0.1 \%$ \\
\hline Median & $-0.2 \%$ & $0.0 \%$ & $0.0 \%$ & $2.5 \%$ & $1.9 \%$ & $0.0 \%$ \\
\hline Maximum & $45.7 \%$ & $1.7 \%$ & $50.0 \%$ & $68.1 \%$ & $330.9 \%$ & $13.9 \%$ \\
\hline Minimum & $-14.6 \%$ & $-2.5 \%$ & $-26.1 \%$ & $-64.8 \%$ & $-100.0 \%$ & $-25.9 \%$ \\
\hline Std. Dev. & $6.6 \%$ & $0.6 \%$ & $11.0 \%$ & $17.4 \%$ & $31.2 \%$ & $3.2 \%$ \\
\hline
\end{tabular}

Source: Own calculations

The large number of indicators which were taken into consideration for the first analysis type, especially as some of them can be considered as proxies for the same factor (e.g. leverage proxy), lead to the necessity of a basic statistical test which would show if certain indicators are correlated. In that situation, those indicators will not be included in the same equation as independent variables. Table 7 presents the correlation coefficient computed for all the indicators that could be used as dependent variables.

Table 7. Correlation coefficient matrix

\begin{tabular}{|c|c|c|c|c|c|c|c|c|c|c|}
\hline & As_Eq & D_Eq & Ltd_Cap & CEO_Ch & Dual & Pens_Rev & Adm_Rev & Rev_Em & Supl_Rev & Rd_Rev \\
\hline As_eq & 1.00 & 0.97 & 0.38 & -0.03 & 0.08 & 0.17 & -0.02 & -0.01 & 0.12 & 0.00 \\
\hline D_eq & & 1.00 & 0.55 & -0.03 & 0.07 & 0.18 & -0.08 & -0.05 & 0.13 & -0.05 \\
\hline Ltd_cap & & & 1.00 & -0.09 & -0.04 & 0.20 & -0.31 & -0.12 & 0.13 & -0.15 \\
\hline CEO_Ch & & & & 1.00 & 0.02 & -0.04 & 0.13 & 0.00 & -0.06 & 0.01 \\
\hline Dual & & & & & 1.00 & 0.15 & 0.04 & 0.28 & 0.27 & 0.05 \\
\hline Pens_rev & & & & & & 1.00 & -0.14 & 0.12 & 0.12 & 0.26 \\
\hline Adm_rev & & & & & & & 1.00 & -0.19 & 0.11 & 0.08 \\
\hline Rev_em & & & & & & & & 1.00 & -0.14 & 0.44 \\
\hline Supl_rev & & & & & & & & & 1.00 & -0.10 \\
\hline Rd_rev & & & & & & & & & & 1.00 \\
\hline
\end{tabular}

Source: Own calculations

As predicted, the indicators used as leverage proxies are significantly positively correlated, which means that only one of these should be used in an equation. I decided to use the leverage (D_Eq), as this is a standard indicator that shows the degree of financial autonomy of a company (the higher this indicator is, the lower the level of the financial autonomy). Also, the correlation coefficient between the revenue per employee and the R\&D expenditure (as percentage of revenue) is positive and relatively high. The negative correlation coefficient between the administrative expenditure (as percentage of total revenue) and the long term debt (as percentage of total capital) is somewhat surprising, at first impression. However, it might point to the fact that when a company has a higher level of long term debt, it has to pay higher interests, so it will try to limit her administrative expenditure (which consist mainly of labour related expenditure and other general expenses).

The second analysis observes if the annual variations of the human capital related indicators have an impact on a company's performance or profitability (pension expenditure, administrative expenditure, supplemental labour expenditure, $\mathrm{R} \& \mathrm{D}$ expenditure - all as percentage of total revenue, the variation of the number of employees and the variation of the revenue per employee). The theoretical assumption and the underlying tested hypothesis is that an increase in employee-related expenditures would attract better trained and more involved employees which should lead to a higher company performance and profitability. Additionally, an increase in the average revenue per employee could signal an increase in employee productivity which should transform in a better working, more efficient company. Similarly, an increase in the number of employees should lead to an increase in a company's performance, provided that it employs the necessary personnel to help increase its activity. To test these hypotheses, I calculated the variations of these indicators and determined their correlation coefficients, which are presented in Table 8. 
Table 8. Additional correlation coefficients

\begin{tabular}{|l|c|c|c|c|c|c|}
\hline & M_ADMIN & M_PENS & M_SUP & M_REVEM & M_EMPL & M_RD \\
\hline M_ADMIN & 1.00 & -0.04 & 0.40 & -0.46 & -0.02 & 0.32 \\
\hline M_PENS & & 1.00 & 0.02 & 0.04 & -0.23 & 0.03 \\
\hline M_SUP & & & 1.00 & -0.22 & -0.04 & 0.31 \\
\hline M_REVEM & & & & 1.00 & -0.26 & -0.25 \\
\hline M_EMPL & & & & & 1.00 & -0.09 \\
\hline M_RD & & & & & & 1.00 \\
\hline
\end{tabular}

Source: Own calculations

The results show a positive, high correlation between the variation of the administrative expenses and the supplemental labour expenses, which means that, when a company has sufficient funds to increase expenditure for administrative purposes, it also invests additional sums in the training and development of its labour-related human capital (supplemental labour related expenses). Also, there is a high negative correlation between the variation of the administrative expenses and the revenue per employee. which suggests that if a company increases their administrative expenses, its employees' performance decreases. Additionally, a high positive correlation can be observed between $\mathrm{R} \& \mathrm{D}$ expenditures and the administrative and supplemental expenses, respectively. This outcome is to be expected because the pharmaceutical sector is one which is highly dependent on R\&D projects.

Taking into account the results previously obtained, by using in a single equation only indicators with a low correlation coefficient, I use consecutively as dependent variables the 5 proxies for profitability (ROE and ROIC) and for performance (GMG, EBMG, NMG). Initially, for each of them, I considered as possible explanatory factors: the current ratio, the leverage, the 2 dummy variables related to the human capital in managerial positions and the human capital related expenses (as percentage of total revenue): pension, administrative, supplemental labour and R\&D. Consequently, in the second analysis, the modification of these human capital related expenses and the variation of the human capital productivity have been included as possible determinants of the 5 dependent variables. For each of these, the equations are constructed as shown in equation(1):

$$
Y_{i, t}=c+\sum_{i=1}^{n} \sum_{j=1}^{S} \sum_{t=1}^{T} \alpha_{i, j, t} \times X_{i, j, t}+\varepsilon_{i, t}(1)
$$

Where Yi,t is the dependent variable for company i in the moment $t$, $\mathrm{c}$ is a constant, $\boldsymbol{\alpha} \mathrm{i}, \mathrm{j}, \mathrm{t}$ is the coefficient that is determined in the regression, $\mathrm{Xi}, \mathrm{j}, \mathrm{t}$ is the independent variable $\mathrm{j}$ for company $\mathrm{i}$ in the moment $\mathrm{t}$

The model was constructed using either fixed or random effects, based on the results of the Hausman test.

If the coefficient for an independent variable is statistically significant, then that variable has an impact on a company's performance or profitability. The sign of the coefficient (positive or negative) shows the relation between the variables: direct or inverse, while the magnitude of the coefficient shows how important is the impact of the independent variable.

\section{Results}

This section presents the empirical findings and interpretations of the research. The first subsection includes the results of the first type of analysis: the impact of the financial, R\&D and human capital related indicators on a company's performance, while the second presents their impact on a company's profitability. The third subsection takes into consideration the variation of human-capital related expenses, productivity and R\&D as possible determinants for both performance and profitability.

\subsection{Performance analysis}

The variables used as proxy for performance are: gross margin (GRMG), EBITDA margin (EBMG) and Net margin (NMG). The potential determining factors are: current ratio, leverage, duality of CEO and Chairman, changing of $\mathrm{CEO}$ and human capital related expenses (as percentage of total revenue): pension, administrative, supplemental labour and $\mathrm{R} \& \mathrm{D}$. If the human related expenses are to be considered as investments a company makes in the development and increased loyalty of its workers than the effects could be delayed a year. Also, the changes made at a managerial level (changing of the CEO or of the Chairman, leading to a duality) need time until their effects are visible. Thus, the model is studied both with contemporaneous variables (the values of the dependent and independent variables from the same year) and with $1 \mathrm{lag}$ (the values of the dependent variables are taken from the year following the values of the independent ones). The results obtained are presented in Table 9.a and b. Based on the Hausman test 
results, the null hypothesis is accepted for EBMG and GRMG, meaning that the model with random effects is best. However, in the case of NMG, fixed effects are used.

Table 9. Determinants of performance indicators

\begin{tabular}{|c|c|c|c|c|c|c|c|}
\hline \multicolumn{4}{|c|}{ a. Simultaneous model } & \multicolumn{4}{|c|}{ b. Lagged model } \\
\hline Variable & EBMG & GRMG & NMG & Variable & EBMG & GRMG & NMG \\
\hline $\mathrm{c}$ & $0.4401 * * *$ & $0.4849^{* * * *}$ & $-0.2931 * *$ & $\mathrm{c}$ & 0.3439 **** & $0.5858 * * *$ & 0.2910 \\
\hline CRAT & -0.0013 & -0.0017 & -0.0203 & CRAT & -0.0018 & -0.0030 & -0.0125 \\
\hline D_EQ & 0.0004 & 0.0001 & 0.0004 & D_EQ & 0.0000 & -0.0021 & -0.0131 \\
\hline RD_REV & -0.0672 & $0.4934 * * *$ & $6.5489^{* * * *}$ & RD_REV(-1) & $0.3571^{* *}$ & $0.3610^{* *}$ & 1.4350 \\
\hline ADM_REV & $-0.4585^{* * *} *$ & $0.4273^{* * *}$ & $-1.2700^{* * * *}$ & ADM_REV(-1) & $-0.2727 * *$ & 0.1631 & -0.7371 \\
\hline PENS_REV & -0.5766 & -1.5095 & -4.4592 & PENS_REV(-1) & -0.2228 & -1.3974 & 0.0496 \\
\hline SUPL_REV & -0.0282 & 0.0037 & $0.3662^{*}$ & SUPL_REV(-1) & $0.0941^{*}$ & 0.0183 & $-0.6602^{* *}$ \\
\hline DUAL & 0.0028 & 0.0088 & $0.2302 * *$ & DUAL $(-1)$ & $-0.0411^{*}$ & 0.0077 & 0.0724 \\
\hline CEO_CH & 0.0178 & 0.0237 & -0.1183 & CEO_CH(-1) & -0.0125 & 0.0185 & $0.3924 * * *$ \\
\hline
\end{tabular}

Based on the simultaneous model, only the administrative expenses have a significant impact on EBMG. However, in the lagged model, the implications change considerably. The expenses related to R\&D and supplemental labour expenses made in the previous year lead to an increase of a company's EBITDA margin. However, the administrative expenses (the day-to-day ones) do not act as an incentive for human capital, but as a normal expense. This means that an increase of these expenses will lead to a reduction of the performance. A curious result is the negative impact that the duality of the CEO and chairman has on the EBMG in the lagged model. In literature, it is considered that the existence of different people as CEO and Chairman should lead, in time, to a higher performance because the independence of the managerial team is, thus, insured.

The results for GRMG are somewhat different from the ones obtained for the EBMG. Firstly, the effect of the CEO change are not significant in either model. However, the impact of R\&D expenses is positive and significant in both equations, but in the simultaneous one the impact is greater. Curiously, the administrative expenses also have a positive effect in the simultaneous model, while in the lagged one the impact becomes insignificant. The expected result would be that these expenses have a negative effect in the simultaneous model, as they are expenses which lead to a decrease of the gross return of the company, as is the case for the other two dependent variables.

In the simultaneous model, the $\mathrm{NMG}$ is positively influenced by the $\mathrm{R} \& \mathrm{D}$ expenses, the supplemental labour related expenses and the duality of the $\mathrm{CEO}$ and chairman and negatively influenced by the adminis trative expenses. Some of these results are in line with existing literature, like the impact of the administrative expenses or the duality of management. However, the positive impact the R\&D and supplemental expenses show that the response to these expenses is almost instantaneous, the end performance improving rapidly. However, the impact of the supplemental labour expenses with a 1-year lag is negative. This shows that a continuous investment in supplemental expenses, like additional training on the job, might prove detrimental to the performance of the company. Additionally, in the lagged model, the variable related to the change of $\mathrm{CEO}$ is significant, with a positive impact, which is in line with existing literature. It might show that changes in the executive management are needed in some moments, but their effects appear after 1 year because the new management team needs time to implement their decisions.

\subsection{Profitability analysis}

A similar analysis is made for the profitability proxies: ROE and ROIC, and the results obtained are presented in Table 10 a. and b. They could provide certain insight in choosing the correct mix of policies that could improve a company's profitability, without affecting its performance. Hausman test showed that fixed effects are the best methodology for both ROE and ROIC, in the simultaneous and lagged models. 
Table 10. Determinants for profitability indicators

\begin{tabular}{lccccc}
\hline \multicolumn{2}{c}{ a. Simultaneous model } & \multicolumn{3}{c}{ b. Lagged model } \\
\hline Variable & ROE & ROIC & Variable & ROE & ROIC \\
\hline c & O.2342*** & 0.1293*** & c & 0.2800** & $0.2396^{* * *}$ \\
CRAT & -0.0012 & -0.0037 & CRAT & -0.0025 & -0.0035 \\
D_EQ & $-0.0400^{* * *}$ & $-0.0126^{*}$ & D_EQ & $-0.0554^{* * *}$ & $-0.0147^{*}$ \\
RD_REV & $1.1106^{* *}$ & $1.3328^{* * *}$ & RD_REV(-1) & -0.0710 & 0.2668 \\
ADM_REV & $-0.6358^{* * *}$ & $-0.5430^{* * *}$ & ADM_REV(-1) & -0.2781 & $-0.3841^{*}$ \\
PENS_REV & 0.7617 & -0.7682 & PENS_REV(-1) & 4.7359 & 0.6141 \\
SUPL_REV & 0.0642 & 0.0635 & SUPL_REV(-1) & -0.0090 & -0.0446 \\
DUAL & $0.0981^{*}$ & $0.0717^{* *}$ & DUAL(-1) & 0.0406 & 0.0114 \\
CEO_CH & -0.0484 & -0.0290 & CEO_CH(-1) & 0.0218 & 0.0473 \\
\hline
\end{tabular}

Source: Own calculations. ${ }^{* * *}, * *$ and $*$ show a level of significance of $1 \%, 5 \%$ and $10 \%$, respectively

For the simultaneous model, four variables have a significant impact on ROE. The leverage has a negative influence on profitability, which is to be expected because it shows that the higher the level of debt in a company, the lower its profitability will be. This is an intuitive result as a higher debt implies a higher interest, which, in turn, affects the bottom line of the company. Also, a negative impact is that of the administrative expenses, which implies the same intuitive explanation. There are, also, two variables with a positive impact: the R\&D expenses and the duality of the CEO and Chairman. While the latter is in line with financial literature, the former requires some further explanations. At a first glance, the R\&D expenses should have, like all other expenses, also a negative impact on the net profit. However, it seems that they start some internal processes in the company which lead to an increase of the company's profit inside the same year, which is also seen in the results obtained for NMG. When the lagged model is observed, only one variable has a significant impact: the leverage, and its sign remains the same. This suggests that whatever impact the human related expenses might have, it should be seen during the year when they are made.

When considering the alternative profitability proxy, ROIC, the results show that, for the simultaneous model, the same four variables have a significant impact. However, for three of the four, the impact seems to be smaller on ROIC than on ROE, with the exception of the R\&D expense which appear to have a somewhat bigger impact. When analyzing the lagged model, the impact of the leverage is still negative, but the impact is, also, smaller on ROIC than on ROE. However, an additional negative impact emerges: the one due to the administrative expenses. This suggests that an increase in these expenses from the previous year would also lead to a decrease of profitability in the current year.

\subsection{Impact of variations of indicators on the performance and profitability of a company}

The subsection presents the results of the second type of analysis: the impact of the variation of several human capital related indicators on the profitability or performance of a company. Because of their high correlation, some indicators were included in separate equations, thus using three different models. Equation 1 includes: the variation of employee productivity, employee number, pension expenses and R\&D expenses, leaving the other two in individual equations: administrative expenses in equation 2 and supplemental expenses in equation 3. As dependent variables, all previously presented 5 indicators are used consecutively.

Similar to the previous analysis, both a contemporaneous and a lagged model was considered, as the impact of all these indicators is possible to appear in both situations. The results obtained for the two profitability proxies are presented in Table 11. a and b. Based on the Hausman test results, fixed effects should be used for ROE in all equations of the simultaneous model and in equations 2 and 3 from the lagged model and for ROIC, in equation 2 from the simultaneous model and the lagged one. The coefficients from the other equations are determined using random effects.

The results showed that neither of the six indicators has a significant effect on ROE, either in the simultaneous model or the lagged one, but the R\&D expenses variation have a significant positive effect on ROIC, in the same year. Based on these findings, the variations of none of the analyzed indicators have a lagged influence on a firm's profitability. However, an increase of the R\&D expenses should lead to an higher ROIC, but not ROE. Also, an increase of administrative expenses, supplemental labour-related ones or the ones to the pension funds did not influence the profitability of a firm in the year they are made, or in the following year. Similarly, neither does an increase in the number of employees or of the employees productivity. 
Table 11. Variations of human related indicators impact on profitability proxies

\begin{tabular}{|c|c|c|c|c|c|c|c|}
\hline \multicolumn{5}{|c|}{ a. Simultaneous model } & \multicolumn{3}{|c|}{ b. Lagged model } \\
\hline Eq. & Variable & ROIC & Eq. & Variable & $\mathrm{ROE}$ & ROIC & \\
\hline \multirow{5}{*}{1} & $\mathrm{C}$ & $0.2206^{* * * *}$ & 0.12 & **** & $\mathrm{C}$ & $0.2356^{* * * *}$ & $0.1296 * * *$ \\
\hline & M_REVEM & 0.1765 & 0.0 & & M_REVEM(-1) & 0.0346 & 0.0935 \\
\hline & M_EMPL & -0.0225 & -0.8 & 20 & M_EMPL(-1) & -0.0647 & -0.0322 \\
\hline & M_PENS & -0.8127 & -0.5 & & M_PENS(-1) & 2.7980 & 0.7805 \\
\hline & M_RD & 1.2603 & 0.93 & $* * *$ & M_RD $(-1)$ & -0.0346 & 0.1068 \\
\hline \multirow{2}{*}{2} & $\mathrm{C}$ & $0.4641 * *$ & 0.22 & **** & $\mathrm{C}$ & $0.3312 * * *$ & $0.2178 * * *$ \\
\hline & M_ADM & -0.0286 & -1.0 & 15 & M_ADM(-1) & -0.1642 & -1.4447 \\
\hline \multirow{2}{*}{3} & $\mathrm{C}$ & $0.4650^{* *}$ & 0.21 & **** & $\mathrm{C}$ & $0.3333^{* * * *}$ & $0.2149 * *$ \\
\hline & M_SUPL & -0.0670 & 0.0 & 4 & M_SUPL(-1) & -0.0733 & -0.1697 \\
\hline
\end{tabular}

Source: Own calculations. $* * * * * *$ and $*$ show a level of significance of $1 \%, 5 \%$ and $10 \%$, respectively

The results obtained for the three performance proxies are presented in Table 12. a and b. Hausman test results suggested using random effects for most of the equations, with the exception of equation 1 for GRMG in both the simultaneous and lagged model and equation 2 for NMG in the simultaneous model, where fixed effects are used.

Results show that the variation of the number of employees and the pension expenditure have no impact on the EBMG in the simultaneous model. However, the increase of employee productivity should lead to a higher performance, which is consistent with financial theory. However, an increase of the R\&D expenses, or the administrative ones or the supplemental ones should lead to a lower performance. Given that these expenses are compared with the EBMG from the same year, the results seem to reinforce the results obtained in the previous subsection. When analysing the lagged model, the findings show that the same two variables also have a significant impact: employee productivity and R\&D expenses. While the coefficient of employee productivity maintains the same sign as the one in the simultaneous model (positive), the one of the R\&D expenses changes from negative to positive. This points out that, even though an increase of the R\&D expenses will lead to a decrease of the current EBMG, it will lead to an increase of the firm's performance in the following year. This is concordant with the idea that R\&D projects are employed to develop new or improved products which lead to an increase in her performance.

The same cannot be said for the increase of pension expenses and supplemental expenses, which only reduce the current EBMG, but do not influence the one from the following year. This suggests that these indicators act only as necessary expenses for the normal activity of the company, not as investments the firm makes in order to improve her performance, evaluated through EBMG. However, the previous analysis showed that supplemental expenses have a positive impact on EBMG which leads to the conclusion that, while increasing them annually (through continuous training of the same employees) will not lead to increases in performance, they are necessary in order to have a high EBMG.

Table 12. Variations of human related indicators impact on performance proxies

\begin{tabular}{|c|c|c|c|c|c|c|c|c|c|}
\hline \multicolumn{5}{|c|}{ a. Simultaneous model } & \multicolumn{5}{|c|}{ b. Lagged model } \\
\hline Eq. & Variable & EBMG & GRMG & NMG & Eq. & Variable & EBMG & GRMG & NMG \\
\hline \multirow{5}{*}{1} & $\mathrm{C}$ & $0.2779^{* * * *}$ & $0.6662^{* * * *}$ & $0.1718^{* * *}$ & \multirow{5}{*}{1} & $\mathrm{C}$ & $0.2796^{* * *} *$ & $0.6677^{*} * *$ & $0.1543^{* * *}$ \\
\hline & M_REVEM & $0.0767 * *$ & 0.0189 & 0.0300 & & M_REVEM(-1) & $0.0792^{* * *} *$ & -0.0273 & $0.4745^{* *}$ \\
\hline & M_EMPL & -0.0208 & $-0.0655^{* * * *}$ & -0.0510 & & M_EMPL(-1) & 0.0041 & $-0.0529 * * *$ & 0.0420 \\
\hline & M_PENS & -0.9444 & -0.7035 & -0.6836 & & M_PENS(-1) & -0.0779 & -1.5609 & 0.9249 \\
\hline & M_RD & $-0.3873^{* *}$ & 0.1199 & $4.2798 * * *$ & & M_RD $(-1)$ & $1.1288^{* * *}$ & 0.1887 & 0.8277 \\
\hline \multirow{2}{*}{2} & $\mathrm{C}$ & $0.2864^{* * * *}$ & $0.6658^{* * * *}$ & $0.1671^{* * * *}$ & \multirow{2}{*}{2} & $\mathrm{C}$ & $0.2806^{* * * *}$ & $0.6646^{* * * *}$ & $0.1681^{* * * *}$ \\
\hline & M_ADM & $-0.4515^{* * * *}$ & $0.1893^{* * *}$ & -0.2165 & & M_ADM(-1) & 0.0543 & $0.1834 * *$ & 0.5922 \\
\hline \multirow{2}{*}{3} & $\mathrm{C}$ & $0.2898^{* * * *}$ & $0.6634 * * *$ & $0.1424 * * *$ & \multirow[t]{2}{*}{3} & $\mathrm{C}$ & $0.2787 * * *$ & $0.6656^{* * * *}$ & $0.1731^{* * * *}$ \\
\hline & M_SUPL & $-0.2175^{* * * *}$ & -0.0359 & $0.7223^{* * * *}$ & & M_SUPL(-1) & 0.0632 & -0.0011 & -0.0577 \\
\hline
\end{tabular}

Source: Own calculations. ***, ** and ${ }^{*}$ show a level of significance of $1 \%, 5 \%$ and $10 \%$, respectively 
Additionally, the increase of labour productivity, of the pension, R\&D or supplemental labour-related expenses seem to have no impact on the GRMG. However, the increase of the number of employees has a detrimental effect on this indicator, suggesting that an increase in personnel does not lead to a similar increase of production and/or profit. Nevertheless, an increase of the administrative expenses should lead to a higher GRMG. For the lagged model, the results show that the variables with a significant impact are the same as in the simultaneous model: variation of employee number and of administrative expenses, and that their coefficients maintain the same sign, suggesting that the impact of these variables can be seen both in the current year and in the following one.

In the case of NMG, only the R\&D expenses and the supplemental ones have an significant impact in the simultaneous model. Their coefficient is positive, meaning that an increase in these expenses leads to a higher firm's performance in the same year. However, the impact of the R\&D expenditures is considerably higher than the supplemental ones (about 6 times higher), which is to be expected considering the importance that these projects have in the pharmaceutical sector. In the lagged model, only the variation of employee productivity has a significant impact on NMG. Its increase by $1 \%$ should lead to a higher NMG in the following year with around $0,47 \%$. Summing up the results of both the simultaneous and lagged models for NMG, an increase in employee productivity should lead to a higher firm's performance in the following year and an increase of the R\&D expenses and the supplemental expenses should also have a positive effect on the performance, but in the same year. At a first glance, this last result might seem contra intuitive due to the method of determining NMG: an increase in expenses should lead to a decrease of the net return, leading, in turn, to a lower NMG. However, these results suggest that the increase of R\&D and supplemental expenses creates additional effects in a company that lead to a higher net return, thus obtaining a positive impact on NMG.

The following section sums up the results obtained in this analysis and presents some conclusions that can be made based on them.

\section{Conclusion and Recommendations}

This study aims to investigate the impact of several human capital related indicators and R\&D expenses on the performance and profitability of listed European companies from the pharmaceutical sector. Financial literature has established that both financial policies and human capital policies should be taken into account when analyzing a company's situation because they are both major factors in determining the future development of that firm.

The company's performance was evaluated through three proxies: the net margin (NMG), the gross margin (GRMG) and the EBITDA margin (EBMG), which offer a relatively different perspective of this issue. The profitability was represented through two rates of return: return on equity (ROE) and return on invested capital (ROIC). The current ratio and the leverage were taken into account in the analysis as control variables. The human capital related indicators included in the analysis can be split into: current expenses (administrative expenses, pension related expenses, supplemental labour related expenses), management structure (CEO-chairman duality and changes of the CEO) and employee productivity (as revenue per employee). The innovation process was also taken into account, through the R\&D expenses, as the studied sector is one highly dependent on such development policies. Including simultaneously all these independent variables in the analysis can be considered a contribution to the vast existing literature, as this is, as far as I know, the only paper that includes both corporate governance indicators (the ones linked to the management structure) and other human capital related indicators. This creates a more detailed picture of the influences that appear in the company through each of the studied policies and the link it develops with other internal company-specific factors.

The database includes the 48 companies from the Thomson Reuters Europe Pharmaceuticals Index, for the period 2011-2017. Missing data or incorrect values for certain indicators lead to the exclusion of some companies from the analysis. Thus, the study was conducted for 26 listed companies which represent more than $79 \%$ of the index's market capitalization. They are from different European countries and different branches of the pharmaceutical sector, thus reducing the possible biases that could influence the results.

The analysis is split in two as demanded by the specific characteristics of the variables. The first type of analysis considers the impact of the independent variables on the performance and profitability indicators. Thus, it determines the magnitude and sign of the connection and it includes all indicators with the exception of employee productivity. In the second type of analysis, the variation of the independent variables is considered, taking into account all R\&D and human-related indicators, excluding the ones related to the management structure, as they are depicted as dummy variables.

The results for the first analysis concerning a company's performance show that each of the three proxies is influenced by some of the considered factors, as presented in Table 13. However, the impact can vary in sign or magnitude. For example, the $R \& D$ expenses improve the gross and net margin in the year they were made, but they influence the EBITDA margin only in the following year. This suggests that R\&D investments are important in the company, regardless of the proxy used, thus confirming the third hypothesis that was tested in this paper and the existing literature (Huang and Hou, 2019).

Additionally, not all current expenses have a positive impact on performance. Pension related expenses have no significant impact (both in the simultaneous and lagged model), while administrative ones have, mainly, a negative one (with the exception of GRMG). The supplemental expenses have a positive impact on the net margin, in the 
current year (and a negative one in the next), and on the EBITDA margin in the next one. This latter category seems to partially confirm the second tested hypothesis of the paper, thus creating a clear separation between itself and the pension and administrative ones. Thus, the findings of both Bendickson and Chandler (2019) and Killins (2020) are supported.

Table 13. Review of factors that influence the performance of a company

\begin{tabular}{|c|c|c|c|c|c|c|c|c|c|}
\hline \multirow{2}{*}{ Variable } & \multicolumn{4}{|c|}{ Simultaneous model } & \multicolumn{5}{|c|}{ Lagged model } \\
\hline & Rd_rev & Adm_rel & Supl_rev & $\overline{\text { Dual }}$ & $\overline{\text { Rd_Rev }}$ & $\overline{\text { Adm_rev }}$ & Supl_rev & $\overline{\text { Dual }}$ & CEO-chan. \\
\hline EBMG & & - & & & + & - & + & - & \\
\hline GRMG & + & + & & & + & & & & \\
\hline $\mathrm{NMG}$ & + & - & + & + & & & - & & + \\
\hline
\end{tabular}

Source: Own calculations. "+" represents a positive significant impact, "-" represents a negative significant impact. A blank cell represents the absence of a significant impact.

Both variables linked to management structure have a positive impact on NMG. These results are in line with some studies from financial literature and confirm the fourth hypothesis of the paper. The positive impact of the CEOchairman duality is linked to the higher level of independency of the management (Erhardt et. al, 2003, Duru et al., 2016), meaning that their decisions are taken in the interest of the whole company, not based on the opinion of one person. The delayed impact of the CEO-change suggests that the changes made by the new management improve the firm's performance (highlighting the importance of the CEO change), but the effects appear in the following year due to the accommodation period the company needs to absorb the new policies (Beatty and Zajac, 1987).

The results obtained for the analysis on a company's profitability provide similar conclusions to the ones related to performance indicators, thus confirming (partially) the third and fourth hypothesis. The only noticeable absence is the positive and significant impact of the supplemental expenses and CEO changes. Additionally, the results show a much more coordinated impact of the analyzed indicators on both proxies, as shown in Table 14. However, the impact of the same variable seems to be marginally bigger on ROE, than on ROIC. This suggests that this rate, which is the primary focus of shareholders, can be influenced to a higher degree by the internal decisions made by the company, like the level of debt that the company should reach (evaluated through the leverage), the level of expenses the company should have to encourage the R\&D activity or to repay its workers.

Table 14. Review of factors that influence the profitability of a company

\begin{tabular}{|c|c|c|c|c|c|c|c|c|}
\hline \multirow{2}{*}{ Indicator } & \multicolumn{4}{|c|}{ Simultaneous model } & \multicolumn{4}{|c|}{ Lagged model } \\
\hline & D_Eq & RD_rev & Adm_rev & Dual & D_Eq & RD_rev & Adm_rev & Dual \\
\hline ROE & - & + & - & + & - & & & \\
\hline ROIC & - & + & - & + & - & & - & \\
\hline
\end{tabular}

Source: Own calculations. "+" represents a positive significant impact, "-" represents a negative significant impact. A blank cell represents the absence of a significant impact.

The second type of analysis shows that the variation of certain human capital related indicators have an impact on the profitability or performance of a company, as shown in Table 15. For example, the increase of R\&D expenses has a positive impact on a firm's profitability, seen as ROIC, but not as its ROE. This seemingly contradicting results can be caused by the different perspectives offered by either proxy. The ROIC indicator, that considers the profitability of a company's activity, would register a positive variation as increasing R\&D investments lead to the development of other products. However, the ROE indicator, which takes into consideration only the company's bottom line, does not register the same immediate result as increases in $\mathrm{R} \& \mathrm{D}$ expenses are usually seen by the firm's creditors as creating new risk sources which leads to an increased interest rate to its existing loans. Increases in current expenses (pension, supplemental or administrative ones) show no significant impact on a company's profitability. This suggests that, while these expenditures are needed, once they reach a certain level, they cannot be used as market signals in order to attract better, more loyal employees or improve a company's image which could, thus, lead to higher profitability. 
Table 15. Review of impact of factors' variation on the profitability/performance of a company

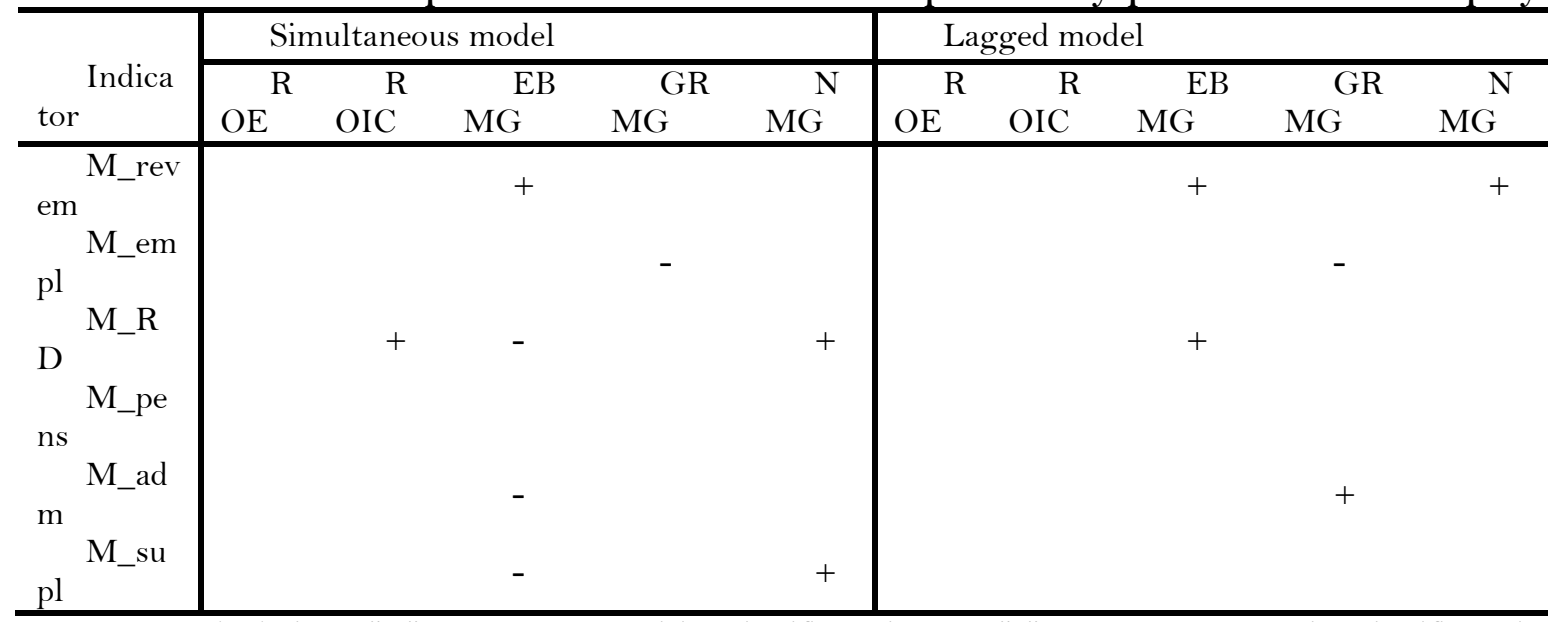

Source: Own calculations. "+" represents a positive significant impact, "-" represents a negative significant impact. A blank cell represents the absence of a significant impact.

The company's performance is positively influenced by an increase in employee productivity, thus confirming the first hypothesis suggested in the paper. This is in line with the findings of Yu et al. (2017) which find a direct connection between employee productivity and its sales. The same results was not obtained for the gross margin, which is, however, influenced negatively by the increase of the employee number. Increases in R\&D investments usually have a positive impact on a firm's performance which suggests that these projects are successful, leading to increases in the company's sales. The different impact that employee productivity and R\&D expenses had on the three performance proxies could be linked to the different perspectives they offer. However, this could also be the result of the relatively low number of companies included in the database. Thus, additional research should be performed on this subject.

Increases in administrative and supplemental expenses also show a variant impact on performance proxies. The only labour related indicator that was constantly not a determinant factor for either the profitability or performance of a company from the database was the pension expense. This suggests that the situation at the end of their career is not of great importance for the personnel in this sector. Thus, a higher investment in pension funds does not attract better employees which would improve the company's performance. This conclusion is not necessarily true. Further investigation should be made, in order to observe if employees are, in fact, highly interested in their pension situation and, thus, prefer to invest on an individual level. This could explain why an increase in administrative expenses (which includes salary expenses) leads to an increase of the company's gross margin in the following year.

These results show that the managerial staff or all other interested parties will have a tough mission when trying to find the correct policies which would lead to the development of a company and the increase of its profitability. They suggest that all these fit together like puzzle pieces in forming the picture of the company and they should be seen as such. Additionally, it is very important to clearly define the desired goal, as policies that improve firm's performance might not influence its profitability (e.g. supplemental labour related expenses). However, some policies have an impact on several indicators (but not all of them), like the CEO-chairman duality which has a positive impact of firm's profitability and its performance (seen as net margin).

The low number of analyzed firms can represent a limitation of the paper, as it hinders its ability to determine conclusions which could be easily generalized to the whole pharmaceutical sector. At best, they should be considered specific to the European sector in a period of relative stable economic environment. For further research, in order to test the robustness of the current paper's conclusions, the database could be extended to include other companies, from Europe or other geographical areas. Additionally, the analysis period could be increased, in order to consider years of financial distress (e.g. the Global Financial Crisis) or of healthcare distress (e.g. the 2020 Pandemic Crisis). Thus, the impact of a non-stable economic environment could be assessed. Another possible research development consists in including other human capital related indicators in the database. For example, variables that were found, by financial literature, to mitigate the impact of the CEO-Chairman duality on a company's profitability (e.g. board independence, board size, information costs, etc.) should be included. 
Akintoye, I., 2008, "Effect of capital structure on firms' performance: the Nigerian experience", European Journal of Economics, Finance and Administrative sciences, 10, pp. 233-243

Avdullahi, A. and Ademi,V.F, 2020, "The Impact of the Entrepreneur and Firm Related Factors on Small and Medium Enterprise Sales Growth", International Journal of Business and Economic Sciences Applied Research, 13, 1, pp. 61-68

Beatty, R. P., and Zajac, E. J., 1987,"CEO change and firm performance in large corporations: Succession effects and manager effects", Strategic Management Journal, 8,4, pp. 305-317

Becker, G., 1962, "Investments in human capital: a theoretical analysis", Journal of Political Economy, 70, pp. 9-44

Becker, B., Huselid, M.A., and Ulrich, D., 2002, "Six key principles for measuring human capital performance in your organization", available at http://mgt2.buffalo.edu/files/faculty/ohr/becker/homepage/management.html (September 2020)

Bendickson, J. and Chandler, T., 2019, "Operational performance: The mediator between human capital developmental programs and financial performance", Journal of Business Research, 94, pp. 162-171

Chen, J., Zhu, Z. and Xie, H., 2004, "Measuring intellectual capital: a new model and empirical study", Journal of Intellectual Capital, 5, pp. 195-212

Cochran, P. L, Wood, R. A. and Jones, T. B., 1985, "The Composition of Boards of Directors and Incidence of Golden Parachutes", Academy of Management Journal, 28, 3, pp. 664-671

Deloof, M., 2003, "Does working capital management affect profitability of Belgian firms?", Journal of Business and Finance, 30, pp. 573-587

Detthamrong, U., Chancharat, N. and Vithessonthi, C., 2017, "Corporate governance, capital structure and firm performance: Evidence from Thailand", Research in International Business and Finance, 42, pp. 689-709

Dewenter, K. and Malatesta, P., 2001, "State-Owned and Privately Owned Firms: An Empirical Analysis of Profitability, Leverage,and Labor Intensity", The American Economic Review, 91, 1, pp. 320-334

Dragot, V., Obreja Brasoveanu, L. and Dragot, I.-M., 2012, Management financiar. Diagnosticul financiar al companiei. Editura Economic Publisher, second edition, Bucharest, Romania

Duru,A., Iyengar, R. and Zampelli, E., 2016, " The dynamic relationship between CEO duality and firm performance: The moderating role of board independence", Journal of Business Research, 69, 10, pp. 4269-4277

Erhardt, N. L., Werbel, J. D. and Shrader, C. B., 2003, "Board of director diversity and firm financial performance", Corporate Governance: An International Review, 11, 2, pp. 102-11

Fedyk, A. and Hodson, J., 2017, "Trading on talent: human capital and firm performance", working paper available at scholar.harvard.edu/files/fedyk/files/humancapital_firmperformance_nov2017.pdf

Grau, A.J. and Reig, A., 2018, " Trade credit and determinants of profitability in Europe. The case of the agri-food industry", International Business Review, 27, 5, pp. 947-957

Hirschey, M. and Wichern, W., 1984, "Accounting and Market-Value Measures of Profitability: Consistency, Determinants, and Uses", Journal of Business \& Economic Statistics, 2, 4, pp. 375-383

Hsu, S., Lin, S., Chen, W. and Huang, J., 2019, CEO duality, information costs, and firm performance", North American Journal of Economics and Finance, In press, available online 19 June 2019

Huang, C-H. and Hou, T.C-T., 2019, "Innovation, research and development, and firm profitability in Taiwan: Causality and determinants", International Review of Economics \& Finance, 59, pp. 385-394

Ibhagui, O. and Olokoyo, F., 2018, "Leverage and firm performance: New evidence on the role of firm size", North American Journal of Economics and Finance, 45, pp. 57-82

Joh, S., 2003, "Corporate governance and firm profitability: evidence from Korea before the economic crisis", Journal of Financial Economics, 68, pp. 287-322

Killins, R., 2020, " Firm-specific, industry-specific and macroeconomic factors of life insurers' profitability: Evidence from Canada", North American Journal of Economics and Finance, 5 1, available online January 2020

Lafuente, E. and Rabetino, R., 2011, " Human capital and growth in Romanian small firms", Journal of Small Business and Enterprise Development, 18, 1, pp. 74-96

List, F., 1841, The national system of political economy, translated by Sampson Lloyd, Longmans, Green, and Co. Publisher, London, UK available at https://www.econlib.org/library/YPDBooks/List/lstNPE.html

Lucas, R., 1988, "On the mechanics of economic development", Journal of Monetary Economics, 22, pp. 3-42

Micah, L, Ofurum, C and Ihendinihu, J., 2012, "Firms financial performance and human resource accounting disclosure in Nigeria", International Journal of Business and Management, 7, 14, pp. 67-75

Mun, S.G. and Jang, S., 2018, "Restaurant operating expenses and their effects on profitability enhancement", International Journal of Hospitability Management, 71, pp 68-76

Murimi, M.M., Ombaka, B. and Muchiri, J., 2019, "Influence of strategic physical resources on performance of small and medium manufacturing enterprises in Kenya", International Journal of Business and Economic Sciences Applied Research, 12, 1, pp. 20-27

Nanda, S. and Panda, A. K., 2018, "The determinants of corporate profitability: an investigation of Indian manufacturing firms", International Journal of Emerging Markets, 13, 1, pp. 66-86

Onkelinx, J., Manolova, T. S. and Edelman, L., 2016, "The human factor: Investments in employee human capital, productivity and SME internationalization", Journal of International Management, 22, pp. 351-364

Pais, M. A. \& Gama, P. M., 2015, "Working capital management and SMEs profitability: Portuguese evidence", International Journal of Management Studies, 1 1, 3, pp. 341-358

Pantea, M., Gligor, D. and Anis, C., 2014, "Economic determinants of Romanian firms' financial performance", Procedia- Social and Behavioral Sciences, 124, pp. 272-281 
Rodrigues, L. \& Rodrigues, L., 2018, "Economic-financial performance of the Brazilian sugarcane energy industry: An empirical evaluation using financial ratio, cluster and discriminant analysis", Biomass and Bioenergy, 108, pp. 289-296

Rumpelt, R. P., 1982, "Diversification strategy and profitability", Strategic Management Journal, 3, 4, pp. 359-369

Say, J-B, 1971, A treatise of political economy, Augustus M. Kelley Publishers, New York, USA

Schultz, T., 1961, "Investment in human capital", American Economic Review, 51, pp. 1-17

Smith, A., 1776, The wealth of nations, Wordsworth Publishing, New York, USA

Teixeira, A., 2002, "On the link between human capital and firm performance: A theoretical and empirical survey", working papers da FEO, no. 121

Veltri, S. and Silvestri, A., 2011, "Direct and indirect effects of human capital on firm value: evidence from Italian companies", Journal of Human Resources Costing \& Accounting, 15, 3, pp. 232-254

Wangari, M.G, Gichuhi, D.M. and Macharia S.M., 2019, "Influence of Eomotional Intelligence on organizational performance among insurance companies in Kenya", International Journal of Business and Economic Sciences Applied Research, 12, 2, pp. 4251

Yu, X., Dosi, G., Grazzi, M. and Lei, J.,2017, " Inside the virtuous circle between productivity, profitability, investment and corporate growth: An anatomy of Chinese industrialization", Research Policy, 46, 5, pp. 1020-1038

This is an Open Access article distributed under the terms of the Creative Commons Attribution Licence 
Appendix 1. Table A1. Companies included in the analysis

\begin{tabular}{|c|c|c|c|c|}
\hline Thomson Reuters Europe Pharmaceuticals Index & Weight \% & In database & \begin{tabular}{|l} 
No. \\
employees \\
$(2018)$ \\
\end{tabular} & $\begin{array}{l}\text { Average } \\
\text { revenue } \\
\text { (mil.euro) }\end{array}$ \\
\hline AB Science SA & 0.02 & NO & - & - \\
\hline Abcam PLC & 0.27 & YES & 948 & 169.47 \\
\hline ALK-Abello A/S & 0.12 & NO & - & - \\
\hline Almirall SA & 0.08 & YES & 1,833 & 717.06 \\
\hline AstraZeneca PLC & 9.08 & NO & - & - \\
\hline Bavarian Nordic A/S & 0.11 & NO & - & - \\
\hline Bayer AG & 10.21 & NO & - & - \\
\hline Biofrontera AG & 0.02 & NO & - & - \\
\hline Biotest AG & 0.06 & NO & - & - \\
\hline Boiron SA & 0.07 & YES & 3,718 & 593.86 \\
\hline BTG PLC & 0.27 & YES & 1,355 & 392.87 \\
\hline Camurus $\mathrm{AB}$ & 0.02 & NO & - & - \\
\hline Celon Pharma SA & 0.04 & NO & - & - \\
\hline ConvaTec Group PLC & 0.43 & YES & 9,541 & 1433.48 \\
\hline Cosmo Pharmaceuticals NV & 0.09 & YES & 301 & 60.65 \\
\hline DBV Technologies SA & 0.14 & NO & - & - \\
\hline Dechra Pharmaceuticals PLC & 0.34 & YES & 1,338 & 297.07 \\
\hline Faes Farma SA & 0.12 & NO & - & - \\
\hline Fagron NV & 0.08 & NO & - & - \\
\hline GlaxoSmithKline PLC & 10.02 & YES & 98,462 & 32211.14 \\
\hline Grifols SA & 1.56 & YES & 18,309 & 3259.44 \\
\hline Guerbet SA & 0.04 & NO & - & - \\
\hline H Lundbeck A/S & 0.44 & YES & 5,068 & 2052.34 \\
\hline Hikma Pharmaceuticals PLC & 0.25 & YES & 8,521 & 1207.36 \\
\hline Indivior PLC & 0.42 & YES & 1,012 & 934.27 \\
\hline Infant Bacterial Therapeutics AB & 0.03 & NO & - & - \\
\hline Ipsen SA & 0.62 & YES & 5,401 & 1472.13 \\
\hline Merck KGaA & 1.32 & YES & 52,880 & 12443.29 \\
\hline Mithra Pharmaceuticals SA & 0.05 & NO & - & - \\
\hline Nicox SA & 0.03 & NO & - & - \\
\hline Novartis AG & 22.21 & YES & 124,000 & 43161.29 \\
\hline Novo Nordisk A/S & 5.88 & YES & 42,688 & 12432.14 \\
\hline Orexo $A B$ & 0.01 & NO & - & - \\
\hline Orion Oyj & 0.46 & YES & 3,168 & 1006.17 \\
\hline Pharma Mar SA & 0.04 & NO & - & - \\
\hline Recipharm AB (publ) & 0.05 & NO & - & - \\
\hline Recordati Industria Chimica e Farmaceutica SpA & 0.41 & YES & 4,176 & 1001.29 \\
\hline Richter Gedeon Vegyeszeti Gyar Nyrt & 0.05 & YES & 12,457 & 1206.5 \\
\hline Roche Holding AG & 17.57 & YES & 93,734 & 41292 \\
\hline Sanofi SA & 8.88 & YES & 106,556 & 34296.86 \\
\hline Shire PLC & 5.55 & YES & 23,044 & 6339.57 \\
\hline STADA Arzneimittel AG & 0.20 & YES & 10,126 & 2026.74 \\
\hline Swedish Orphan Biovitrum AB & 0.39 & YES & 850 & 363.2 \\
\hline Ucb SA & 0.97 & YES & 7,478 & 3676.86 \\
\hline Vectura Group PLC & 0.08 & NO & - & - \\
\hline Vifor Pharma AG & 0.78 & YES & 2,650 & 8012.05 \\
\hline Virbac SA & 0.07 & NO & - & - \\
\hline Wilson Therapeutics AB & 0.06 & NO & - & - \\
\hline Total & 100.00 & 79.53 & & \\
\hline
\end{tabular}

